This item was submitted to Loughborough's Research Repository by the author.

Items in Figshare are protected by copyright, with all rights reserved, unless otherwise indicated.

Control modes and mechanisms in construction project teams: drivers and consequences

PLEASE CITE THE PUBLISHED VERSION

http://dx.doi.org/10.1080/01446191003702500

PUBLISHER

Routledge (@ Taylor \& Francis)

VERSION

AM (Accepted Manuscript)

LICENCE

CC BY-NC-ND 4.0

REPOSITORY RECORD

Tuuli, Martin Morgan, Steve Rowlinson, and Tas Yong Koh. 2019. "Control Modes and Mechanisms in Construction Project Teams: Drivers and Consequences”. figshare. https://hdl.handle.net/2134/6655. 
This item was submitted to Loughborough's Institutional Repository (https://dspace.lboro.ac.uk/) by the author and is made available under the following Creative Commons Licence conditions.

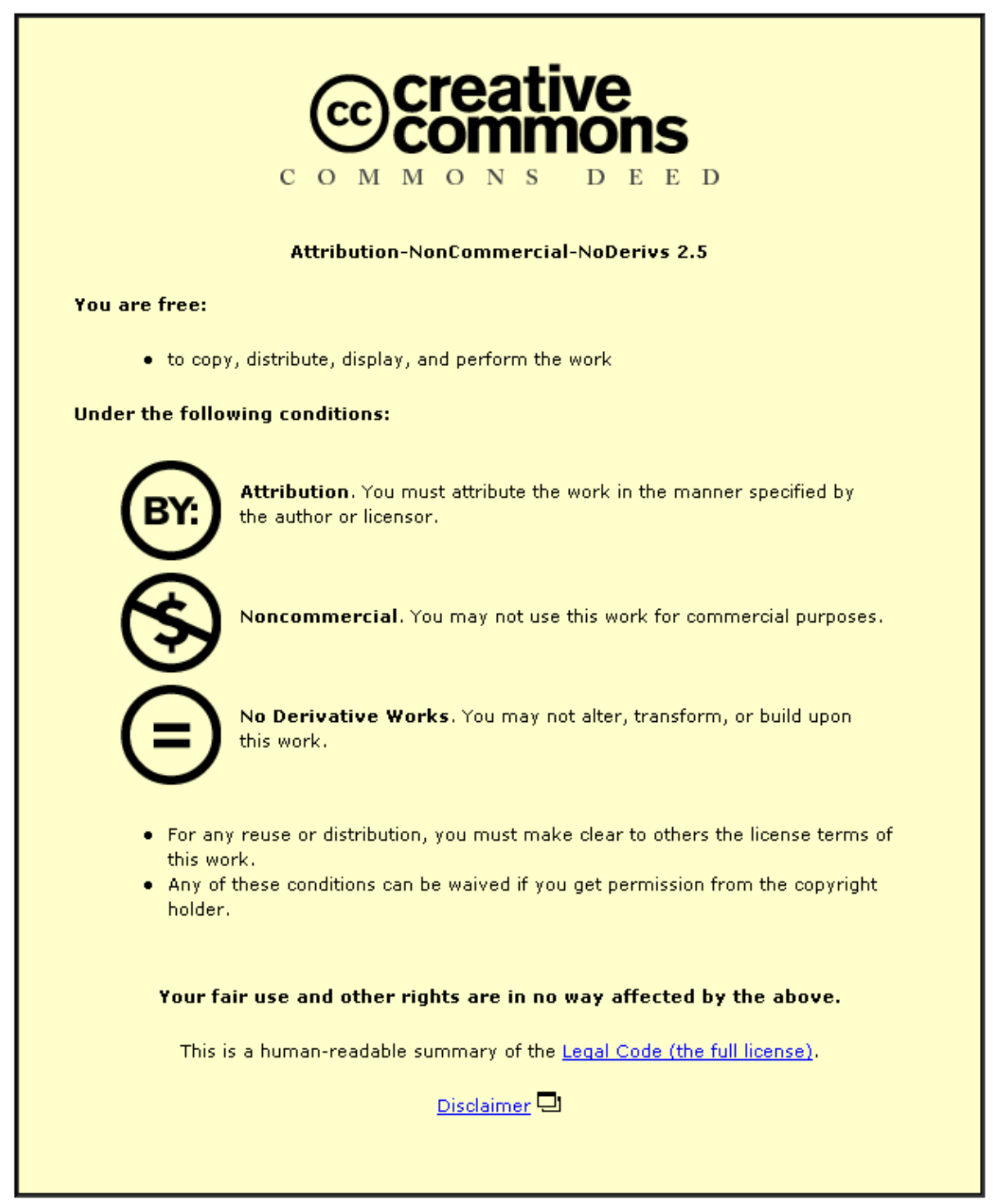

For the full text of this licence, please go to: http://creativecommons.org/licenses/by-nc-nd/2.5/ 


\title{
CONTROL MODES AND MECHANISMS IN CONSTRUCTION PROJECT TEAMS: DRIVERS AND CONSEQUENCES
}

\author{
MARTIN MORGAN TUULI ${ }^{1}$, STEVE ROWLINSON ${ }^{2}$ and TAS YONG $\mathrm{KOH}^{2}$ \\ ${ }^{1}$ Department of Civil and Building Engineering, Loughborough University, Loughborough, \\ $U K$ \\ ${ }^{2}$ Department of Real Estate and Construction, University of Hong Kong, Hong Kong
}

\begin{abstract}
Control is purposive or goal directed, hence, there are underlying drivers and consequences of the exercise of control modes and mechanisms. In response to recent empirical findings that cast doubts on the empowerment-control incompatibility thesis, the broader question of whether control is predominantly "controlling” or rather supportive in work environments is addressed. Drivers and consequences of control modes and mechanisms in five project teams involved in two ongoing construction projects in Hong Kong are explored. As an interpretive and exploratory study, a qualitative research design and the case study approach in particular was appropriate. Framework, category formation and cross-case analysis techniques were employed to analyse data collected through documentary analysis, passive observations and semi-structured face-to-face interviews. The exercise of control is driven by a range of factors emanating from the individual-, team-, organization- and project-level. Control modes and mechanisms also have performance related consequences for individuals, teams and organizations and are predominantly attributable to self-based control mechanisms. Preliminary evidence of the important link between self-control/empowerment and performance is therefore provided which is instructive for the performance improvement agenda in the construction industry.
\end{abstract}

Keywords: empowerment, drivers of control, Hong Kong, consequences of control, portfolio of control 


\section{INTRODUCTION}

It is in the nature of high risk undertakings, such as construction projects, to implement and use control mechanisms although they may not be visible to those being controlled (Badenfelt, 2007, Kamminga and Van der Meer-Kooistra, 2007). Control mechanisms are particularly used in organisations to achieve goal congruence and reinforce corporate values and beliefs (Sisaye, 1998). The pervasive use of control mechanisms in construction project environments, however, appears to be at variance with the view that the site-based nature of projects with the attendant complexity and uncertainty provides an ideal climate for the empowerment of individuals and teams. Lack of empowerment of key project participants has, however, been cited as a problematic issue in successful partnering and other collaborative practices advocated for performance improvement in project contexts (c.f. Ng et al. 2002). Control has often been viewed as incommensurate with empowerment which emphasizes the expansion of employee autonomy and responsibility through the removal of control-oriented management approaches to create a work environment that permits employees to apply their full potential in the performance of tasks (Tuuli et al. in press). Yet, recent empirical research (c.f. Lambe et al., 2009, Nieminen and Lehtonen, 2008, Dewettinck, 2004) cast doubts on the empowerment-control incompatibility thesis and suggest that both empowerment and control are valuable in optimizing the work context. Dewettinck (2004) for instance found that empowerment contributes to positive work outcomes through motivational mechanisms while the positive effects of control occur through mechanisms that lead to the fulfilment of employee's basic need for competence development and challenging tasks. The interplay between control and empowerment and the underlying drivers of their use as well as the consequences that ensue therefore require further empirical exploration. 
The trajectory of control and empowerment research also appears to be shifting towards identifying the underlying values of exercising control and whether control is predominantly “controlling” (i.e. prescriptive of behaviours and outcomes) or rather supportive (i.e. enabling or facilitating) in nature (Adler and Borys, 1996, Dewettinck, 2004). In response to this focus, the aim of the study is to identify the drivers and consequences of the exercise of control modes and mechanisms in construction project teams. This is part of a larger research project exploring the manifestations of empowerment and control in project teams, findings from which have partially been reported by Tuuli and his colleagues (c.f. Tuuli, 2009, Tuuli et al., 2009, Tuuli et al., in press, Tuuli and Rowlinson, 2009). In the sections that follow, a framework of control modes is advanced to place the study in perspective and provide a reference for the identification of the drivers and consequences of the control modes. The research design is subsequently outlined and the findings from the analysis of the drivers and consequences of control in five project teams involved in two ongoing construction projects presented and discussed.

\section{DEVELOPMENT OF A CONTROL FRAMEWORK}

The organization and management literature views control as encompassing all the devices and systems employed to ensure that the behaviour and decisions of organizational constituents are consistent with the organization's goals, objectives and strategies (Merchant and Stede, 2007, Flamholtz et al., 1985). Four modes of control have been advanced over the years, from the three originally proposed by Ouchi (1979), and account for the range of mechanisms (i.e. devices and systems) through which organizational control is exercised (Kirsch, 1996, Kirsch, 1997, Leifer and Mills, 1996, Nieminen and Lehtonen, 2008)outcome-, behaviour-, clan- and self-based controls. Outcome- and behaviour-based controls are formal/bureaucratic control modes which attempt to restrict outcomes or behaviours 
while clan- and self-based controls depict informal control modes which attempt to induce a value or belief change (Flamholtz et al., 1985). Formal controls therefore rely on surveillance and close evaluation, build on the comparison of outcomes or behaviours with predetermined ones. Clan-based control relies on informal socialization, such as shared values, beliefs and norms, to eliminate goal incongruence. Self-based control is the scenario where one sets his/her own targets in relation to the needs of the organization or task, monitors his/her own behaviours and when necessary changes them in accordance with the self-set or agreed targets (Kirsch, 1996). Self-based control is therefore synonymous with the notion of empowerment. Table 1 summarizes the key characteristics of the four modes of control, as adapted from Nieminen and Lehtonen (2008), with additional information from prior studies (e.g. Eisenhardt, 1985, Kirsch, 1996, Kirsch, 1997, Leifer and Mills, 1996, Ouchi, 1979, Sharma, 1997), and provides an organizing framework for studying control in project teams. Control in this context is viewed as encompassing all the devices and systems employed to ensure that acts, behaviours, outcomes and decisions of individuals, teams and organizations are consistent with meeting organizational or project goals, objectives and strategies (c.f. Merchant and Stede, 2007, Flamholtz et al., 1985, Nieminen and Lehtonen, 2008).

\section{INSERT TABLE 1 HERE}

Recent empirical work in the project context (e.g. Badenfelt, 2007, Langfield-Smith, 2008, Nieminen and Lehtonen, 2008) have confirmed the four-modes of control framework described above and indeed, the existence of a portfolio of control modes comprising both formal and informal control mechanisms. What remains unknown, however, are the underlying drivers that determine the use of one mode of control or the other or a combination of modes of control and the consequences that ensue. In the information systems project management context, Kirsh (1997) identified task characteristics, knowledge and 
skills of the stakeholders and role expectations as key antecedents of control. However, no known study in the construction management domain has explored the dynamics of control and the underlying factors that engender the use control modes and mechanisms. An attempt is therefore made here to bridge this knowledge gap. Traditionally, contextual factors that determine control related concepts have been examined from three levels; individual-, teamand organization-level (Tuuli and Rowlinson, 2010). Recently, Kirsch (2004) also identified several factors influencing the choice of control modes from the project, stakeholder and global contexts. In the construction industry context in particular, project-level is an important source of drivers and it transcends the individual, team and the organisational contexts. The development of control theory is therefore best served by an expanded focus on the factors at all relevant levels that influence the use of control mechanisms.

\section{RESEARCH DESIGN AND METHODOLOGY}

\section{Design of the Study and Data Collection}

As an interpretive and exploratory study, a qualitative research design and the case study approach was particularly appropriate as it encompasses the holistic, in-depth study of a phenomenon using a variety of data sources and procedures (Yin, 2003). Two cases were selected for study; an infrastructure project and a building project. While the projects are comparable in some respects, consistent with an attempt at literal replication (c.f. Yin, 2003), they also differ in two key criteria; project lifecycle at start of case study and the project delivery/procurement system in use. These two characteristics have been shown to induce substantial variation in the authority, control and responsibility structures within the multiorganizational project environment (c.f. Bryman et al., 1987, Newcombe, 1996, Rowlinson et al., 1993, Walker, 2002). The two projects therefore provided consistent, yet differentiated information rich settings for study that allowed the emergence and interplay of various other 
contextual factors. While the two projects were the primary focus of the study, the units of analysis were the five embedded project management teams of the contracting parties in the projects.

Three data collection techniques were employed; documentary data analyses, observations and interviews. Documentary analysis was used to gain a deeper understanding of the projects and to identify project specific issues with control implications. Passive observations were undertaken at project meetings and site visits to capture authority, responsibility and control related issues in an emergent and emic manner. The interviews elicited information about manifestations (incidents) of control (covering the range of control modes as discussed and presented in Table 1) and the underlying drivers and consequences of the control modes. The Critical Incident Technique (c.f. Flanagan, 1954) was used to encourage respondents to recall control episodes on the project and to describe them in as much detail as possible. A total of 30 semi-structured face-to-face interviews were conducted with carefully selected team members (17 on Project Alpha and 13 on Project Beta), carefully selected on the basis of their critical roles as either controllers or controlees. The interviewees role descriptions on the projects included project manager, site agent, quantity surveyor, quality control manager, project architect, resident engineer, project clerk of works, etc.. All but one interview were tape recorded and transcribed verbatim. By employing three different data sources, convergence of information was achieved through triangulation. In particular, inconsistencies in information from one source (e.g. interviews) were clarified using data from the other sources (e.g. documentary analysis or observations). Thus, collaborative evidence on pertinent issues was obtained from multiple sources to assert their credibility. 


\section{Background of Projects and Teams}

\section{Project Alpha}

The project involves the construction of a $1.1 \mathrm{~km}$ elevated viaduct which is an integral part of a $7.6 \mathrm{~km}$ long major highway infrastructure undertaking. The project is delivered under a traditional design-bid-build approach with a non-contractual partnering arrangement in place. The contract is a re-measurement type with a price fluctuation clause and awarded for an initial contract period of 40 months and at an initial contract sum of HK\$1,012 million. There are three primary teams; the client's team (i.e. Client-Alpha, 5 members of which 3 were interviewed), the consultant's team (i.e. Consul-Alpha, 14 members of which 7 were interviewed) and the contractor's team (i.e. Contra-Alpha, 10 members of which 7 were interviewed). The study of Project Alpha began about a year after the project started and lasted 30 months.

The client is a government department with responsibility for the planning, design, construction and maintenance of the public road system and railway networks. A team of 5 is assembled in-house to coordinate the client's input into the project. The consulting engineer is a Hong Kong-based international engineering consulting firm with more than 60 years experience in the delivery of projects in the fields of building, civil engineering and industrial construction. Consul-Alpha team comprises The Engineer and a team of Resident Site Staff (RSS). The contractor is a joint venture between two Hong Kong-based French sister companies and a Chinese state-owned company. The companies brought together their enormous international expertise and local experience to forge a partnership.

\section{Project Beta}

The project is Phase 4 (of six phases) of a public-rental housing programme involving the construction of three 41-storey blocks, estimated to provide a total of about 2,300 units of 
rental apartments. The value of the works is estimated at about HK\$434 million and is contracted out for an initial period of 36 months. The works are procured broadly under a traditional design-bid-build approach with a non-contractual partnering arrangement in place. Special conditions of contract cater for six work packages contracted under a Modified Guaranteed Maximum Price (MGMP) arrangement which collectively make-up about 31\% of the contract sum. The study began slightly more than a year after the project started, and lasted 15 months. There are two primary teams in the project; the client's team (i.e. DualBeta, 15 members of which 6 were interviewed) and the contractor's team (i.e. Contra-Beta, 10 members of which 7 were interviewed).

The client is a statutory body that develops and implements the government's public housing programme. The project management team comprises head office staff and a site team who together play a dual role as both consultant and client, responding to design issues and making the approvals often reserved for the client's team in a traditional project set-up. The contractor is part of a diversified conglomerate and plays a leading role in property development, construction and materials supply. Their choice as contractor for Project Beta was an assertion of their role as one of the leading contractors in the public housing market with a reputation of excellence and quality in housing delivery.

\section{Data Analysis Strategy}

The data was analysed in three stages. In the first stage, control mechanisms were identified and classified into the control modes framework as outlined in Table 1 . The results of the first stage analysis are reported elsewhere by Tuuli and his colleagues (Tuuli et al, in press, Tuuli, 2009, Tuuli et al., 2009). The second stage of the analyses identified the drivers of control from the detailed descriptions of the control mechanisms identified in stage one, the transcripts of interviews and notes from the documentary analysis and passive observations. 
Both explicit and implied reasons for the implementation of particular control mechanisms or the conditions that facilitated or fostered such implementation formed the basis of the driver identification. Here, category formation through "open coding”, i.e. applying conceptual labels (c.f. Corbin and Strauss, 2008), was used inductively to describe the identified drivers of control. Where the details of the drivers matched conceptual descriptions from literature, such labels were used (e.g. project complexity, organization culture, etc.), while other labels were suggested directly from the data itself (c.f. Corbin and Strauss, 2008). In a further step, the individual-, team-, project- and organization-level was used as the a priori framework to group the identified drivers of control. The third stage of the analyses process involved identifying consequences of the control modes and a similar process as that used to identify the drivers was employed. However, the identified consequences were classified into those for individuals, teams and organizations.

\section{Credibility and Trustworthiness Measures}

Credibility and trustworthiness are key issues in qualitative research and in case studies in particular. Demonstrating credibility and trustworthiness in the design and execution of qualitative research is particularly important in establishing confidence in the findings and conclusions drawn. Several measures were taken in the case studies and were mainly based on the recommendations of Butterfield et al. (2005);

- Triangulation in the data collection: three sources of data were relied upon in each case study; documentary, observations and interviews. This enabled verification of emergent issues from multiple sources to achieve convergence.

- Descriptive validity was ensured by working with verbatim transcripts of interviews, photocopied documentary evidence and notes and direct quotations as much as possible from the observations. 
- Interview fidelity was achieved through consistent application of the interview protocol but also probing as much as possible to discover the different perspectives of the interviewees.

- Theoretical validity: This measure is demonstrated in the discussion of the case study findings, where references are made to previous research to show how the emergent themes from the cases are consistent or inconsistent. The aim therefore is to demonstrate theoretical agreement and convergence with previous work.

\section{FINDINGS}

\section{Drivers of Control in Project Alpha}

\section{Client-Alpha Team}

The drivers of control in Client-Alpha team are depicted in Table 2 (see column 5). Several of the drivers trigger multiple control modes. For example, organization culture which is characterised by "rule following” spurs procedures and standard setting (e.g. Project management handbook, project budget, etc. which are formal controls) while the constant reference to the organization's mission statement is also attributable to the culture of accountability in the client's organization (i.e. clan control). Some drivers, such as trust (i.e. within and across organizations) have a double-edged-sword effect. When trust exists, there is limited use of behaviour- and outcome-based controls but more clan controls are employed. However, when trust is absent there is an increase in the use of both behaviour- and outcomebased controls.

Consul-Alpha Team 
Table 2 also depicts the drivers of the control modes in the Consul-Alpha team (see column 5). There is no driver of control from the project-level. Trust, experience, organization rank and nationality \& culture trigger multiple control modes and in some circumstances limit the use of behaviour- and outcome-based controls. Personality and top management support are key drivers of clan control modes. The following remarks of the Chief Engineer illustrates how personality influences the effective use of clan controls such as partnering and joint problem solving;

"You see, work as a team is a slogan, right? But how to work as a team depends on many things, depends on personality, for example, for those individuals involved in the project, if some people have a strong character, they may not like to share with others and very often it will create frictions, right? That's why in the workshops [partnering workshops] we always emphasize we have to be 'hard on the issue but soft on the people', so that people can be a bit open”

\section{Contra-Alpha Team}

The drivers of control modes in Contra-Alpha team are also shown in Table 2 (see column 5) and most of them are the same as those identified in both Client-Alpha and Consul-Alpha. Three drivers are, however, unique to Contra-Alpha; knowledge of past performance, project complexity and joint venture arrangement. While knowledge of past performance largely limits behaviour-based controls such as monitoring mechanisms, project complexity results in the introduction of several behaviour-based controls (e.g. operating guidelines on launching girder). Similarly, the contractor organization status as a joint venture triggers several controls, both formal and informal (e.g. Project Joint Venture Board, goal alignment, identity orientation, etc.) which otherwise would have been unnecessary. 


\title{
Drivers of Control in Project Beta
}

\author{
Dual-Beta Team
}

Table 3 depicts the drivers of the different control modes in Dual-Beta team and influence the use of multiple modes of control (see columns 4 and 5). For example, the pilot/experimental status of the project influences the use of the dispute resolution system to mitigate disputes (i.e. behaviour-based control). At the same time, this driver triggers a desire to succeed across the organization and had an impact on the selection of project team members while also arousing public interest in the project with the attendant pressure to succeed (i.e. clan controls). Also, while a driver such as trust leads to limited use of outcomebased and behaviour-based control modes, these appear to have been replaced by clan control mechanisms.

\section{Contra-Beta Team}

Table 3 also shows the drivers of control in Contra-Beta team (see column 5). Most drivers trigger multiple modes of control. For example, the pilot/experimental status of the project triggers public pressure which is a form of clan control. At the same time, this driver creates the opportunity for the contractor's involvement in design and enables the contractor to further role out Corporate Social Responsibility (CSR) initiatives (i.e. self-control mechanisms). However, some drivers (e.g. status perception/expectation, open mindedness, etc.) influence the exercise of only self-control mechanisms. Also, other drivers (e.g. trust and knowledge of past performance) actually engender limited use of outcome-based and behaviour-based control mechanisms. Indirectly then, they appear to reinforce self-control through the belief that the contractor can be trusted to do the right thing through self- 
regulation. This is manifested in the client's attitude to control in situations where there is trust versus situations where little trust exists. The Senior Architect rationalizes this as follows;

"I think with trust, ...... if I give the instruction to the contractor, and I trust that they can do it.... according to what I want. .....I can simply give the order, and I know that it will be done. And this is the basic trust, right? But if I don't trust him, well I should say, you should let me know the details how you are going to do it and I may have to be involved in the process as he is doing it. So I have to go to site and inspect the works, and maybe a few times, and modify some of the areas identified. If I trust him, I may not have to do this. So trust will decide how much involvement there will be in the implementation process.”

INSERT TABLE 3 HERE

\section{Consequences of Control in Project Alpha}

\section{Client-Alpha Team}

The exercise of control in Client-Alpha produced several as depicted in Table 4 (see column 5). The relatively low number of claims and the apparently successful teamwork compared with the client's other projects (e.g. adjoining projects) is attributed to a commitment to work together and jointly solve problems and the robustness of the contract. The client and individual project participants are also quite satisfied with the project so far. Indeed, this project is the only one in the client's road programme that is on track to being delivered ahead of schedule. In terms of cost, it is projected that the out-turn cost will be up to $10 \%$ more than the cost at tender, due mainly to fluctuations, yet the client is still satisfied with that level of cost. Several control measures also yielded less non-compliance in Temporary Transport Arrangements (TTAs). There is also evidence of learning in Client-Alpha team. 
For several of the team members, this is the first project they have been involved in from inception and looking forward to taking it all the way to the close-out stage.

\section{Consul-Alpha Team}

The consequences of control in Consul-Alpha team are also depicted in Table 4 (see column 5). Less claims and TTA non-compliance are consequences for organizations while teamwork is a consequence for both individuals and teams. The emergent consequences for individuals are learning and job satisfaction. Indeed, job satisfaction was one of the most recurrent themes in the interviews with Consul-Alpha team members. The comments of a Resident Engineer epitomise the pervasive feeling of satisfaction;

"I find it quite satisfying in saying that the bridge is built and completed on time, without any accident. I think that's the most rewarding part, no accident on the project being built at this high level [average height above ground is $65 \mathrm{~m}]$ is very important"

\section{Contra-Alpha Team}

The control modes in Contra-Alpha team had several consequences as also shown in Table 4 (see column 5). Most of the consequences are the same as those identified in Client-Alpha and Consul-Alpha teams above. Creativity \& innovation and time savings are, however, peculiar to Contra-Alpha team. The complex nature of the project was particularly the driver of the creative and innovative potential of the contractor. The consequences in Contra-Alpha where predominantly attributable to self-control mechanisms (see column 4 in Table 4). 


\section{Consequences of Control in Project Beta}

Dual-Beta Team

The exercise of control (i.e. mainly self-control) produced several consequences in Dual-Beta as shown in Table 5 (see column 5). For many Dual-Beta team members, several project characteristics present them with new experiences [e.g. GMP, Independent Checking Unit (ICU), use of precast elements, etc.] and, thus, there was a learning curve especially at the beginning of the project. The client is particularly satisfied with the progress being made and is optimistic. The contractor's alternative design proposals as part of the MGMP packages (i.e. self-control mechanisms) have also yielded both time and cost savings. So far, two of such proposals (i.e. gabion wall to replace sheet piling and fibre glass railings in place of earthing for metal railings) have led to a net savings of about HK\$1.5 million which have since been shared (50/50) between the contractor and the client.

\section{Contra-Beta Team}

The consequences of control identified in Contra-Beta team are attributable mainly to the exercise of several self-control mechanisms, as in Dual-Beta (see Table 5, columns 4 and 5). The MGMP packages and the ensuing contractor's involvement in the design are seen as creating an opportunity to tap the contractor's experience and expertise to improve buidability. This consequently unleashed the contractor's creative and innovative potential as evident in the various alternative proposals that emerged, resulting in considerable time and cost savings. The success of the contractor's CSR programmes in which the surrounding neighbours were engaged in the project is also evident in the comparatively less complaints received with regards to the works, a stack contrast with the experience in past projects. 


\section{CROSS-TEAM COMPARISONS AND DISCUSSIONS}

\section{Drivers}

Control is purposive or goal directed (Kirsch, 1997), hence, there are underlying drivers of control modes and the mechanisms through which they are exercised in project teams. As the results show, control is driven by a range of factors emanating from the individual-, team-, organization- and project-level as discussed in detail below.

\section{Individual-level}

The individual-level drivers of control in the 5 teams across the two projects are summarized in the upper part of Table 6. No driver is common to all five teams; however, trust and experience are drivers of control in teams across both projects. While experience in Project Alpha was in relation to the project product and construction methods (i.e. RSS's inadequate experience in precast viaduct bridges and segmental construction), in Project Beta, experience was in relation to the procurement arrangement. Both teams in Project Beta had no prior experience in the GMP arrangement. The experience scenarios in both projects required a learning curve to get up to speed and during this period more control was evident in some cases and completely absent in others. During this period, trust also played a key role. Where there was trust less monitoring was evident and vice versa (i.e. the double-edgedsword effect referred to earlier). Some individual-level drivers, status perception and open mindedness, are specific to Contra-Beta team. Status perception is a driver for excellence over and above what is expected by the organization. Although open mindedness is an attribute of the Dual-Beta team, it is responsible for the emergence and sustenance of selfcontrol in Contra-Beta. In a traditional design-bid-build project arrangement, Dual-Beta team's role would have been to provide the contractor with the designs to build. Due to the built in flexibility through the MGMP arrangement, however, the contractor was empowered 
to design and make alternative design proposals. An open mind was therefore imperative to the possibility of accepting and subsequently implementing such contractor's proposed initiatives.

\section{Team-level}

Experience and trust are also team-level drivers of control as depicted in the second-quarter of Table 6. There is no team-level driver of control in Contra-Beta. In contrast to the individual-level manifestations of experience and trust, at the team-level the emphasis was to what extent the collective team experience or trust in the team as a whole triggers control. In terms of experience, the individual-level effect was similar to the team-level effect since there were no experienced individuals to make-up for the inexperience of other team members, thus, the teams in both projects had to go through the learning curve. In the case of trust, however, there is evidence that more trustworthy team members in both projects provided a bridge for new team members whose credibility was yet to be ascertained. Thus, when an issue arose, the presence or involvement of more trustworthy team members was sufficient for the team to be considered trustworthy as well, resulting in less control. However, trust manifested as a double-edged-sword in both projects where its presence limited behaviourand outcome-based controls but resulted in the increase of clan controls and vice versa.

\section{Organization-level}

The organization-level drivers of control across the 5 teams are also shown in the thirdquarter of Table 6. Top management support is a driver of control in all teams. However, its manifestation and the control modes it triggers differ in the two projects. In Project Alpha, top management support manifests as top management articulation of desire to work in partnership with other parties to jointly solve project problems. This call resonated consistently across all the teams in Project Alpha and is a key driver of clan control 
mechanisms such as partnering, joint problem solving and mutual objectives. In Project Beta, however, top management support manifests in top management provision of additional resources and the affordance of greater leverage for the site team to test and develop ideas. Support in Project Beta therefore encourages proactive attitude, thus, a driver of self-control. Organization culture is also a common driver across teams in both projects and its effects in the client related teams is similar. As teams from government departments, both teams were influenced by a bureaucratic culture. However, the influence of organization culture on controls in Client-Alpha is more pervasive than on controls in Dual-Beta. A plausible explanation for the different influence of organization culture in the two teams may stem from the division of the client's organization that Dual-Beta team originates and the fact that the team plays a dual role as client and designer. As the R \& D section, the Development and Procurement Sub-division has been in the forefront of the client's innovative initiatives. A culture of proactivity seems to have been built into the way things are done, cultivated through the supportive nature of the organizational environment. As Table 5 also shows, some drivers are team specific, reflecting the peculiar team or organization circumstances. The joint venture origins of Contra-Alpha and the R \& D origins of Dual-Beta are the most prominent of such team or organization specific circumstances.

\section{Project-level}

The project-level drivers of control are also shown in the bottom of Table 6. Project status and complexity are drivers in teams across both teams. There are similarities and differences in their manifestations and the controls they trigger. In Project Alpha, project status is a function of the importance and priority of the project to the client and, thus, triggers more reporting to the client's top management who wanted to stay informed on all relevant issues on the project. Project Beta on the other hand is an experimental/pilot project. Its experimental/pilot status and initiatives such as the MGMP packages triggered public interest 
with the consequences being pressure on the project team to succeed. An "open book accounting” approach was also instituted to help monitor cost. INSERT TABLE 6 HERE

\section{Consequences}

The findings show that the exercise of control in its diverse forms is associated with several consequences for individuals, teams and organizations as discussed in further detail below.

\section{For Individuals}

Table 7 (i.e. upper part) depicts the consequences of control for individuals across the two projects. Job satisfaction and learning manifest in all teams and are primarily attributed to various self-control mechanisms. There is, however, an interesting distinction in the teams regarding how control leads to both job satisfaction and learning. In Client-Alpha and Consul-Alpha teams, job satisfaction and learning are a result of mainly self-control mechanisms exercised by Contra-Alpha and not from the self-control of Client-Alpha or Consul-Alpha teams themselves. Job satisfaction and learning in Contra-Alpha, Dual-Beta and Contra-Beta teams, however, emerge from their own self-control mechanisms. There are also team specific consequences in Contra-Beta team; opportunity and creativity \& innovation. These outcomes are also a direct result of self-control mechanisms, especially the MGMP arrangement with the resultant opportunity for involvement in design that also allows individuals to suggest ideas.

\section{For Teams}

The consequences of control for teams across the five teams are also shown in Table 7 (i.e. middle part). All the consequences for teams are project specific and attributable to different control modes. Teamwork, which is specific to Project Alpha, is a consequence of clan control mechanisms while learning, specific to Project Beta, is primarily an outcome of selfcontrol mechanisms. However, mutual understanding which is specific to Contra-beta team is 
attributable to behaviour-based control mechanisms. In this regard, handbooks and manuals are seen as a means of obtaining mutual understanding among the team members on what direction or procedure to pursue under different project scenarios. While learning, opportunity and creativity and innovation for teams are similar to the consequences for individuals, here the emphasis is on what was learnt as a team, what opportunities are created for teams and the overall pattern of creative \& innovative behaviours enacted by teams.

\section{For Organizations}

The consequences of control for organizations are also depicted in Table 7 (i.e. bottom part). Taken together, there are comparatively more consequences for organizations than consequences for teams and individuals. Three consequences, client satisfaction, creativity \& innovation and time savings, are common outcomes in both projects (i.e. Project Alpha and Beta). The majority of the consequences of control for organizations are, however, project specific. For example, less claims \& non-compliance and teamwork are specific to Project Alpha while cost savings, learning, opportunity and less public complaints are specific to Project Beta. Almost all the consequences of control in Project Beta are attributable to selfcontrol mechanisms. This is interesting, considering that there are comparatively more behaviour-, outcome- and clan-based control mechanisms in Project Beta than self-based control mechanisms. On the contrary, while some consequences of control in Project Alpha are attributable to single modes of control (i.e. mainly clan and self-control mechanisms), other consequences are the outcome of multiple modes of control (i.e. mainly a combination of behaviour-based and self-control).

INSERT TABLE 7 HERE 


\section{CONCLUSION AND IMPLICATIONS}

There are underlying drivers and consequences of the exercise of control modes and mechanisms in project teams. A set of drivers emanating from the individual-, team-, organization- and project-level were identified and shown to: (a) depend on project or team specific circumstances; (b) trigger different control modes in different projects or teams depending on the nature of their manifestation; (c) trigger multiple control modes; and (d) have "double-edged-sword" effects in the manner in which they influence control modes. A greater insight into the previously unexplored area of drivers of control in construction project context is provided which suggests that project participants and sponsors must recognize that peculiar project and team conditions may warrant the development and implementation of team or project specific control mechanisms. Also, drivers are not necessarily associated with particular control modes; hence, the manifestation of a driver may provide a better clue to the control mode it engenders. The link between specific drivers and particular modes of control is therefore complex and requires more systematic examination. Further, the "double-edged-sword” effects of some drivers, especially trust, experience and knowledge of past performance, suggest that some drivers can promote the exercise of control in very subtle ways that may not be recognised by those being controlled (c.f. Badenfelt, 2007, Kamminga and Van der Meer-Kooistra, 2007). Thus, the mere reduction in or perceived absence of formal controls may not necessarily signal that other forms of control are not present.

The control modes and mechanisms also have consequences for individuals, teams and organizations. Notably, the outcomes of control are predominantly attributable to self-control mechanisms. Whether this is really the case or, as Nieminen and Lehtonen (2008) suggest, that formal controls become so innate that they are no longer viewed as controls and hence, 
as having consequences is unclear. Perrow (1986) has also earlier pointed out that organizational constituents resent "bad" rules, but take for granted or barely notice "good" rules. On the evidence of the identified consequences in the case studies and their link to control modes, self-control clearly emerges as an important driver in engendering positive outcomes for individuals, teams and organizations. This echoes prior findings of the productive nature of self-regulation/empowerment and its appropriateness in complex and uncertain work settings such as construction (c.f. Kanter, 1977, Greasley et al., 2005, Langfred, 2000, Loosemore et al., 2003).

The consequences of control for individuals, teams or organizations are also predominantly performance related (e.g. satisfaction, learning, opportunity, creativity and innovation, teamwork, etc.). This is an interesting finding in view of the fact that these outcomes are predominantly the result of self-control/empowerment. Indeed, the perceived performance consequences of self-control/empowerment has a long history and it remains a key presumption of empowerment theory that empowered individuals and teams perform better than those relatively less empowered (c.f. Thomas and Velthouse, 1990, Kirkman and Rosen, 1997, Kirkman and Rosen, 1999, Tuuli, 2009, Tuuli and Rowlinson, 2009). It is particularly remarkable that the performance consequences of self-control are not only for individuals, but teams and organizations as well. Self-control may therefore have greater implications for the performance improvement agenda in the construction industry. Cost, time, teamwork and public complaints are areas the construction industry has consistently underperformed but which, as the findings here suggests, could benefit from individual, team and organization self-control in project settings. There is therefore preliminary evidence of the important link between self-control/empowerment and performance which provide support for the adoption 
of empowerment within the construction industry as a key to the industry's performance improvement drive (c.f. M4I, 2000, Nesan and Holt, 1999).

It is also instructive that some of the positive consequences were attributed to behaviour-, outcome- and clan-based control mechanisms while no negative consequences arising from them was evident. This suggests that the form of control exercised in the teams examined may not have debilitating effects as some have surmised (e.g. Cicmil and Hodgson, 2006, Fournier and Grey, 2000, Hodgson, 2004). In accord with the earlier findings of Dewettinck (2004) therefore both control and empowerment contribute positively to work outcomes, especially where there is coherence and no obvious conflict among the different control modes (Nieminen and Lehtonen, 2008).

Caution should, however, be exercised in interpreting the findings of this study because of their case specific nature and the possibility of self-serving attribution bias, which manifests itself in the tendency to take credit for successes and blame others for failure (Bradley, 1978, Miller and Ross, 1975). By not concurrently assessing respondents' perceived level of selfcontrol/empowerment, we were unable to test whether respondents less empowered made external attributions of negative consequences or whether those more empowered made internal attributions regarding the positive consequences identified.

\section{REFERENCES}

ADLER, P. S. \& BORYS, B. (1996) Two types of bureaucracy: Enabling and coercive. Administrative Science Quarterly, 41 (1), 61-89. 
BADENFELT, U. (2007) Trust and control in the early phases of target cost contracts. IN BOYD, D. (Ed.) Proceedings of the 23rd ARCOM Annual Conference 2007. Belfast, Northern Ireland, Association of Researchers in Construction Management, pp. 23-32. BRADLEY, G. W. (1978) Self-serving biases in the attribution process: A re-examination of the fact or fiction question. Journal of Personality and Social Psychology, 36 56-71.

BRYMAN, A., BRESNEN, M., BEARDSWORTH, A. D., FORD, J. \& KEIL, E. T. (1987) The concept of the temporary system: The case of the construction project. IN DI THOMASO, N. \& BACHARACH, S. (Eds.) Research in the sociology of organizations. JAI Press, Greenwich, pp. 253-283.

CICMIL, S. \& HODGSON, D. (2006) New possibilities for project management theory: A critical engagement. Project Management Journal, 37 (3), 111-122.

CORBIN, J. \& STRAUSS, A. (2008) Basics of qualitative research: Techniques and procedures for developing grounded theory, 3rd Edn. Sage Publications, Los Angeles, Calif.

DEWETTINCK, K. (2004) Empowerment and control dynamics in service contexts: Conceptual exploration and empirical validation of the impact on frontline employee affect and performance, Doctor in Applied Economics Thesis, Department of Management and Organization, Ghent University, Ghent, Belgium.

EISENHARDT, K. M. (1985) Control: Organizational and economic approaches. Management Science, 31 (2), 134-149.

FLAMHOLTZ, E. G., DAS, T. K. \& TSUI, A. (1985) Toward an integrative framework of organizational control. Accounting, Organizations and Society, 10 (1), 35-50.

FLANAGAN, J. C. (1954) The critical incident technique. Psychological Bulletin, 51 (4), 327-358. 
FOURNIER, V. \& GREY, C. (2000) At the critical moment: Conditions and prospects for critical management studies. Human Relations, 53 (1), 7-32.

GREASLEY, K., BRYMAN, A., DAINTY, A. R. J., PRICE, A. D. F., SOETANTO, R. \& KING, N. (2005) Employee perceptions of empowerment. Employee Relations, 27 (4), 354-368.

HODGSON, D. E. (2004) Project work: The legacy of bureaucratic control in the postbureaucratic organization. Organization, 11 (1), 81-100.

KAMMINGA, P. E. \& VAN DER MEER-KOOISTRA, J. (2007) Management control patterns in joint venture relationships: A model and an exploratory study. Accounting, Organizations and Society, 32 (1-2), 131-154.

KANTER, R. M. (1977) Men and women of the corporation, 1st Edn. Basic Books, New York.

KIRKMAN, B. L. \& ROSEN, B. (1997) A model of work team empowerment. IN PASMORE, W. A. \& WOODMAN, R. W. (Eds.) Research in organizational change and development. JAI Press, Oxford, pp. 131-167.

KIRKMAN, B. L. \& ROSEN, B. (1999) Beyond self-management: Antecedents and consequences of team empowerment. Academy of Management Journal, 42 (1), 5874.

KIRSCH, L. J. (1996) The management of complex tasks in organizations: Controlling the systems development process. Organization Science, 7 (1), 1-21.

KIRSCH, L. J. (1997) Portfolios of control modes and IS project management. Information Systems Research, 8 (3), 215-239.

KIRSCH, L. J. (2004) Deploying common systems globally: The dynamics of control. Information Systems Research, 15 (4), 374-395. 
LAMBE, C. J., WEBB, K. L. \& ISHIDA, C. (2009) Self-managing selling teams and team performance: The complementary roles of empowerment and control. Industrial Marketing Management, 38 (1), 5-16.

LANGFIELD-SMITH, K. (2008) The relations between transactional characteristics, trust and risk in the start-up phase of a collaborative alliance. Management Accounting Research, 19 (4), 344-364.

LANGFRED, C. W. (2000) The paradox of self-management: individual and group autonomy in work groups. Journal of Organizational Behaviour, 21 (5), 563-585.

LEIFER, R. \& MILLS, P. K. (1996) An information processing approach for deciding upon control strategies and reducing control loss in emerging organizations. Journal of Management, 22 (1), 113-137.

LOOSEMORE, M., DAINTY, A. R. J. \& LINGARD, H. (2003) Human resource management in construction projects: strategic and operational approaches, Edn. Spon, London.

M4I (2000) A commitment to people "our biggest asset". Report of the Movement for Innovation (M4I) Working Group on "Respect for People": London, UK.

MERCHANT, K. A. \& STEDE, W. A. V. D. (2007) Management control systems: Performance measurement, evaluation and incentives, 2nd Edn. Financial Times/Prentice Hall, Harlow, England.

MILLER, D. T. \& ROSS, M. (1975) Self-serving biases in attribution of causality: Fact or fiction? Psychological Bulletin, 82 213-225.

NESAN, L. J. \& HOLT, G. D. (1999) Empowerment in construction: The way forward for performance improvement, Research Studies Press, Baldock, Herts.

NEWCOMBE, R. (1996) Empowering the construction project team. International Journal of Project Management, 14 (2), 75-80. 
NG, S. T., ROSE, T. M., MAK, M. \& CHEN, S. E. (2002) Problematic issues associated with project partnering-the contractor perspective. International Journal of Project Management, 20 (6), 437-449.

NIEMINEN, A. \& LEHTONEN, M. (2008) Organizational control in programme teams: An empirical study in change programme context. International Journal of Project Management, 26 (1), 63-72.

OUCHI, W. G. (1979) A conceptual framework for the design of organizational control mechanisms. Management Science, 25 (9), 833-848.

PERROW, C. (1986) Complex organizations: A critical essay, 3rd Edn. Random House, New York.

ROWLINSON, S. M., HO, T. K. K. \& PO-HUNG, Y. (1993) Leadership style of construction managers in Hong Kong. Construction Management \& Economics, 11 (6), 455-465.

SHARMA, A. (1997) Professional as agent: knowledge asymmetry in agency exchange. Academy of Management Review, 22 (3), 758-798.

SISAYE, S. (1998) An overview of the social and behavioural sciences approaches in management control research. Behavioural Research in Accounting, 10 11-26.

THOMAS, K. W. \& VELTHOUSE, B. A. (1990) Cognitive elements of empowerment: An interpretive model of intrinsic task motivation. Academy of Management Journal, 15 (4), 666-681.

TUULI, M. M. (2009) Empowerment and control dynamics in project teams: A multilevel examination of the antecedents and job performance consequences, Ph.D Thesis, Department of Real Estate \& Construction, The University of Hong Kong, Hong Kong. 
TUULI, M. M. \& ROWLINSON, S. (2010) What empowers individuals and teams in project settings? A critical incident analysis. Engineering, Construction and Architectural Management, 17 (1), 9-20.

TUULI, M. M. \& ROWLINSON, S. (2009) Empowerment in project teams: A multilevel examination of the job performance implications. Construction Management \& Economics, 27 (5), 473-498.

TUULI, M. M., ROWLINSON, S. \& KOH, T. Y. (2009) Portfolio of control modes in project teams: A Hong Kong case study. IN DAINTY, A. (Ed.) Proceedings of $25^{\text {th }}$ Association of Researchers in Construction Management Conference (ARCOM) 2009 Annual Conference. Nottingham, UK., ARCOM, pp. 927-937.

TUULI, M. M., ROWLINSON, S. \& KOH, T. Y. (in press) Dynamics of control in project teams. Construction Management \& Economics.

WALKER, A. (2002) Project management in construction, 4th Edn. Blackwell, Oxford, UK.

YIN, R. K. (2003) Case study research: Design and methods, 3rd Edn. Sage Publications, Thousand Oaks, California. 
Table 1: Conceptual Framework of Control Modes and Control Mechanisms

\begin{tabular}{|c|c|c|c|c|}
\hline \multirow{2}{*}{ Characteristics } & \multicolumn{2}{|c|}{ Formal/Bureaucratic Control } & \multicolumn{2}{|c|}{ Informal Control } \\
\hline & Outcome-based & Behaviour-based & Clan-based & Self-based \\
\hline Focus of control & $\begin{array}{l}\text { Outcomes; } \\
\text { results }\end{array}$ & $\begin{array}{l}\text { Behaviour; } \\
\text { actions }\end{array}$ & Values, beliefs & Self-regulation \\
\hline Basis of control & $\begin{array}{l}\text { Rules, } \\
\text { surveillance }\end{array}$ & $\begin{array}{l}\text { Rules, } \\
\text { surveillance }\end{array}$ & $\begin{array}{l}\text { Shared values, shared } \\
\text { norms }\end{array}$ & Self-monitoring \\
\hline Source of control & $\begin{array}{l}\text { Organization or } \\
\text { External Parties }\end{array}$ & $\begin{array}{l}\text { Organization or } \\
\text { External Parties }\end{array}$ & $\begin{array}{l}\text { Group members, } \\
\text { associations }\end{array}$ & $\begin{array}{l}\text { Individuals, } \\
\text { groups }\end{array}$ \\
\hline $\begin{array}{l}\text { Ideal conditions } \\
\text { for use }\end{array}$ & $\begin{array}{l}\text { Task outcomes } \\
\text { are known and } \\
\text { measureable; } \\
\text { explicit link } \\
\text { exists between } \\
\text { extrinsic rewards } \\
\text { and producing } \\
\text { outcomes }\end{array}$ & $\begin{array}{l}\text { Knowledge of the } \\
\text { transformation } \\
\text { process; } \\
\text { behaviour } \\
\text { observable; } \\
\text { explicit link } \\
\text { between rewards } \\
\text { and behaviours }\end{array}$ & $\begin{array}{l}\text { Imperfect knowledge of } \\
\text { the transformation } \\
\text { process; immeasurable } \\
\text { outputs; behaviour } \\
\text { observable; rewards } \\
\text { linked to values }\end{array}$ & $\begin{array}{l}\text { Imperfect } \\
\text { knowledge of } \\
\text { transformation } \\
\text { process, } \\
\text { immeasurable } \\
\text { outputs, low } \\
\text { behaviour } \\
\text { observability }\end{array}$ \\
\hline $\begin{array}{l}\text { Examples } \\
\text { control } \\
\text { mechanisms }\end{array}$ & $\begin{array}{l}\text { Performance } \\
\text { standards, } \\
\text { targets, etc. }\end{array}$ & $\begin{array}{l}\text { Codes of conduct, } \\
\text { contracts, } \\
\text { handbooks, etc. }\end{array}$ & $\begin{array}{l}\text { Mission statement, core } \\
\text { values, peer pressure, } \\
\text { culture, norm. }\end{array}$ & $\begin{array}{l}\text { Autonomy, } \\
\text { decision-making } \\
\text { power, intrinsic } \\
\text { motivation, etc. }\end{array}$ \\
\hline
\end{tabular}




\begin{tabular}{|c|c|c|c|c|}
\hline Driver & Descriptions & Driver Level & Control Mode & Team \\
\hline Nationality \& Culture & $\begin{array}{l}\text { Multiple nationalities and cultural backgrounds created a sense of cultural } \\
\text { awareness resulting in adjustment of acceptable behaviours, } \\
\text { communication, personality and attitudes. }\end{array}$ & Individual & Clan-/Behaviour-based & $\begin{array}{l}\text { Client/Consul } \\
\text { /Contra }\end{array}$ \\
\hline Top Management Support & $\begin{array}{l}\text { Articulation of desire to work in partnership with other parties to jointly } \\
\text { solve project problems. }\end{array}$ & Organization & Clan-based & $\begin{array}{l}\text { Client/Consul } \\
\text { /Contra }\end{array}$ \\
\hline Trust-Project Team & $\begin{array}{l}\text { Good relationships, mutual understanding, communication, and joint } \\
\text { problem solving. }\end{array}$ & $\begin{array}{l}\text { Individual/Team/ } \\
\text { Organization }\end{array}$ & Clan-/Self-based & $\begin{array}{l}\text { Client/Consul } \\
\text { /Contra }\end{array}$ \\
\hline Trust-Client-Alpha & $\begin{array}{l}\text { Many years of working together with the client resulted in trust by past } \\
\text { performance. }\end{array}$ & Individual & $\begin{array}{l}\text { Outcome-/Behaviour- } \\
\text { based }\end{array}$ & Client \\
\hline Trust-Consul-Alpha & $\begin{array}{l}\text { Senior management had hands-off approach and importance placed on } \\
\text { information received from lower-level staff. }\end{array}$ & Individual & $\begin{array}{l}\text { Outcome-/Behaviour- } \\
\text { /Self-based }\end{array}$ & Consul \\
\hline Trust-Contra-Alpha & $\begin{array}{l}\text { Trust was fundamental in the joint venture and manifested in the partners } \\
\text { finding no need to introduce any extra controls or surveillance to protect } \\
\text { their interest. There was also articulation of strong belief that everyone was } \\
\text { working in the interest of the project. }\end{array}$ & $\begin{array}{l}\text { Individual/Team/ } \\
\text { Organization }\end{array}$ & $\begin{array}{l}\text { Behaviour/Outcome- } \\
\text { based }\end{array}$ & Contra \\
\hline Project Status & Project is part of a high profile road programme requiring more attention. & Project & Behaviour-based & Client \\
\hline Personality & $\begin{array}{l}\text { Strong, protective and dominant personalities and apathetic behaviours } \\
\text { often seen as a threat to partnering and teamwork were absent. }\end{array}$ & Individual & Clan-based & $\begin{array}{l}\text { Client/Consul } \\
\text { /Contra }\end{array}$ \\
\hline Organization Culture & $\begin{array}{l}\text { The organization emphasizes accountability and transparency. Fear of } \\
\text { blame or prosecution drives a "rule following culture". }\end{array}$ & Organization & $\begin{array}{l}\text { Clan-/Behaviour- } \\
\text { /Outcome-based }\end{array}$ & Client \\
\hline Lack of Experience & $\begin{array}{l}\text { The Resident Site Staff (RSS) team had inadequate experience in precast } \\
\text { viaduct bridge construction. }\end{array}$ & Individual/Team & $\begin{array}{l}\text { Behaviour-/Outcome- } \\
\text { based }\end{array}$ & $\begin{array}{l}\text { Consul/Contr } \\
\text { a }\end{array}$ \\
\hline Organization Rank & $\begin{array}{l}\text { Higher rank personnel (e.g. Chief Resident Engineer, The Engineer, etc.) } \\
\text { were seen as having greater opportunities to exercise authority granted } \\
\text { through the contract or the organization. }\end{array}$ & Individual & $\begin{array}{l}\text { Behaviour-/Outcome-/ } \\
\text { Clan-/Self- based }\end{array}$ & $\begin{array}{l}\text { Consul/Contr } \\
\text { a }\end{array}$ \\
\hline $\begin{array}{l}\text { Knowledge of Past } \\
\text { Performance }\end{array}$ & $\begin{array}{l}\text { The joint venture partner contractors have a long working experience with } \\
\text { both the client and consultant. }\end{array}$ & Organization & Behaviour-based & Contra \\
\hline Project Complexity & $\begin{array}{l}\text { There are peculiar features of the project that made it a complex } \\
\text { undertaking; size, location (vertically and laterally), technical requirements, } \\
\text { heavy precast elements, curvature of viaducts, number of bridges (i.e. } 21 \text { in } \\
\text { total), extensive work at height, etc. }\end{array}$ & Project & $\begin{array}{l}\text { Outcome- / Behaviour- } \\
\text { based }\end{array}$ & Contra \\
\hline Joint Venture & $\begin{array}{l}\text { The risk of self-interest because of the joint venture status of the contractor } \\
\text { was mitigated with specific controls. }\end{array}$ & Organization & $\begin{array}{l}\text { Behaviour-/Outcome- } \\
\text { /Clan-/Self-based }\end{array}$ & Contra \\
\hline
\end{tabular}


Table 3: Drivers of Modes of Control in Project Beta

\begin{tabular}{|c|c|c|c|c|}
\hline Driver & Descriptions & Driver Level & Control Mode & Team \\
\hline Trust-Dual-Beta Team & $\begin{array}{l}\text { There was mutual understanding and communication which resulted in } \\
\text { more proactive attitudes. }\end{array}$ & Individual & Clan/Self-based & Dual \\
\hline Organization Culture & $\begin{array}{l}\text { Fear of blame or prosecution drives a "rule following culture", which } \\
\text { leads to inflexibility and a deterministic culture. }\end{array}$ & Organization & $\begin{array}{l}\text { Clan/Behaviour- } \\
\text { /Outcome-based }\end{array}$ & Dual \\
\hline Status of Project & $\begin{array}{l}\text { The pilot/experimental status of the project was a driver of several } \\
\text { controls. }\end{array}$ & Project & $\begin{array}{l}\text { Clan/self/Behaviour- } \\
\text { based }\end{array}$ & Dual/Contra \\
\hline $\begin{array}{l}\text { Experience with } \quad \text { GMP } \\
\text { Arrangement }\end{array}$ & $\begin{array}{l}\text { The GMP arrangement was new to both the client and contractor. Thus, } \\
\text { they were both very cautious in their approach. }\end{array}$ & $\begin{array}{l}\text { Individual/Team/ } \\
\text { Organization }\end{array}$ & Behaviour-based & Dual/Contra \\
\hline Top Management Support & $\begin{array}{l}\text { The team was afforded flexibility to test ideas and there was willingness } \\
\text { to consider proposals from the team. }\end{array}$ & Organization & Self-based & Dual/Contra \\
\hline Procurement Arrangement & $\begin{array}{l}\text { The introduction of GMP to an otherwise traditional design-bid-build } \\
\text { contract, introduced elements of design and built in the form of the } \\
\text { contractor's involvement in the design }\end{array}$ & Project & $\begin{array}{l}\text { Clan-/Self-/ } \\
\text { Outcome-/ } \\
\text { Behaviour-based }\end{array}$ & Dual/Contra \\
\hline Trust-Client & $\begin{array}{l}\text { Trust manifests itself in less documentation (e.g. letters), monitoring and } \\
\text { involvement in implementation process. }\end{array}$ & Organization & $\begin{array}{l}\text { Outcome-/Behaviour- } \\
\text { based }\end{array}$ & Contra \\
\hline Project Complexity & $\begin{array}{l}\text { Project was a site specific design compared with the standard block } \\
\text { design the client has often used. There were also contractor's proposed } \\
\text { innovations which the client's team was not familiar with. }\end{array}$ & Project & $\begin{array}{l}\text { Outcome-/Behaviour- } \\
\text { based }\end{array}$ & Contra \\
\hline Knowledge of Past Performance & $\begin{array}{l}\text { The contractor has a long working experience with the client which } \\
\text { increased trust. }\end{array}$ & Organization & Behaviour-based & Contra \\
\hline $\begin{array}{l}\text { Status Perception/ } \\
\text { Expectation }\end{array}$ & $\begin{array}{l}\text { Project leader is a Senior Project Manager/Assistant General Manager } \\
\text { compared with the other project leaders in the company who are just } \\
\text { Project Managers. }\end{array}$ & Individual & Self-based & Contra \\
\hline Open Mindedness & $\begin{array}{l}\text { Given the atypical nature of the project, there was adjustment in attitude } \\
\text { to be more open to suggestions and proposals. }\end{array}$ & Individual & Self-based & Contra \\
\hline Risk Perception & Potential risk of failure was a constraint to greater self-control. & Organization & Self-based & Contra \\
\hline Project Implementation Division & $\begin{array}{l}\text { The Development and Procurement }(\mathrm{R} \& \mathrm{D}) \text { Sub-division had no prior } \\
\text { experience in project implementation. }\end{array}$ & Organization & $\begin{array}{l}\text { Clan-/Self-/ } \\
\text { Outcome-/ } \\
\text { Behaviour-based }\end{array}$ & Contra \\
\hline
\end{tabular}


Table 4: Consequences of Modes of Control in Project Alpha

\begin{tabular}{|c|c|c|c|c|}
\hline Consequences & Descriptions & Consequences for & Control Mode & Team \\
\hline Less Claims & $\begin{array}{l}\text { Claims on the project are primarily due to inclement weather (i.e. } 65 \% \text { of } \\
\text { notified claims). }\end{array}$ & Organizations & Clan Control & $\begin{array}{l}\text { Client/Consul/ } \\
\text { Contra }\end{array}$ \\
\hline Client Satisfaction & $\begin{array}{l}\text { The client is generally satisfied with the project so far especially in terms of } \\
\text { safety, cost and time. }\end{array}$ & Organization & $\begin{array}{l}\text { Behaviour-/ } \\
\text { Self-based }\end{array}$ & Client \\
\hline Less TTA Non-compliance & $\begin{array}{l}\text { This project has experienced less total non-compliance in Temporary Transport } \\
\text { Arrangements (TTA) than most of the client's projects. This is attributed to } \\
\text { several interventions initiated jointly by the RSS and the contractor. }\end{array}$ & Organizations & $\begin{array}{l}\text { Behaviour- } \\
\text { /Self- based }\end{array}$ & $\begin{array}{l}\text { Client/Consul/ } \\
\text { Contra }\end{array}$ \\
\hline Job Satisfaction & $\begin{array}{l}\text { There were expressions of how enjoyable, interesting, satisfying and personally } \\
\text { rewarding it is to be part of the construction of a landmark edifice and seeing it } \\
\text { on tract to be delivered on time and without any serious accident. }\end{array}$ & Individuals & Self-based & $\begin{array}{l}\text { Client/Consul/ } \\
\text { Contra }\end{array}$ \\
\hline Learning & $\begin{array}{l}\text { The project created an opportunity for several individuals to go through the } \\
\text { project lifecycle for the first time and expand their knowledge base. The } \\
\text { innovative initiatives were also an opportunity to learn (e.g. the use of the new } \\
\text { generation launching girder). }\end{array}$ & Individuals & Self-based & $\begin{array}{l}\text { Client/Consul/ } \\
\text { Contra }\end{array}$ \\
\hline Teamwork & $\begin{array}{l}\text { Teamwork manifested itself in the mutual understanding, joint problem solving } \\
\text { and the commitment to mutual goals and objectives. }\end{array}$ & $\begin{array}{l}\text { Teams/ } \\
\text { Organizations }\end{array}$ & Clan-based & $\begin{array}{l}\text { Client/Consul/ } \\
\text { Contra }\end{array}$ \\
\hline Creativity and Innovation & $\begin{array}{l}\text { The complex and technically challenging nature of the project provided an } \\
\text { opportunity for the contractor to propose alternative designs and methods of } \\
\text { construction resulting in considerable time } \& \text { cost savings. }\end{array}$ & Organizations & Self-based & Contra \\
\hline Time Savings & $\begin{array}{l}\text { Contractor's innovative construction methods resulted in considerable savings } \\
\text { in time. }\end{array}$ & Organizations & Self-based & Contra \\
\hline
\end{tabular}


Table 5: Consequences of Modes of Control in Dual-Beta Team

\begin{tabular}{|c|c|c|c|c|}
\hline Consequences & Typical Manifestations & Consequences for & Control Mode & Team \\
\hline Cost Savings & $\begin{array}{l}\text { Contractor's innovative proposals resulted in cost savings that were shared } \\
\text { equally between the client and contractor. }\end{array}$ & Organizations & Self-based & Dual/Contra \\
\hline Time Savings & $\begin{array}{l}\text { Contractor's innovative proposals resulted in considerable savings in time } \\
\text { which will lead to early occupancy for tenants. }\end{array}$ & Organizations & Self-based & Dual/Contra \\
\hline Learning & $\begin{array}{l}\text { There is evidence of learning at the individual-, team- and organization- } \\
\text { level. Learning was in terms of ICU procedures, GMP arrangement, } \\
\text { testing and role out of initiatives (e.g. vertical greening, gabion wall, etc.). }\end{array}$ & $\begin{array}{l}\text { Individuals/Teams/ } \\
\text { Organizations }\end{array}$ & $\begin{array}{l}\text { Self-control/ } \\
\text { Outcome-based }\end{array}$ & Dual/Contra \\
\hline Job Satisfaction & $\begin{array}{l}\text { This manifested in expressions of how enjoyable the project experience } \\
\text { was and seeing suggested ideas actually being used on a live project. }\end{array}$ & Individuals & Self-based & Dual/Contra \\
\hline Client Satisfaction & $\begin{array}{l}\text { The client in general is satisfied with the process so far. The client is also } \\
\text { happy with the contractor's performance so far. }\end{array}$ & Organization & Self-based & Dual \\
\hline Mutual Understanding & $\begin{array}{l}\text { Management systems, manuals and handbooks were viewed as a means of } \\
\text { providing clear directions to all team members in terms of role } \\
\text { expectations. }\end{array}$ & Teams & Behaviour-based & Contra \\
\hline Opportunity & $\begin{array}{l}\text { The contractor had the opportunity to propose alternative designs in what } \\
\text { otherwise is a traditional procurement arrangement. This trickled down } \\
\text { and ideas were invited from every team member for trial and } \\
\text { development. }\end{array}$ & $\begin{array}{l}\text { Individuals/Teams/ } \\
\text { Organizations }\end{array}$ & Self-control & Contra \\
\hline Less Public Complaints & $\begin{array}{l}\text { This project experienced considerably much less public complaints } \\
\text { compared with similar past projects. This was attributed to the contractors } \\
\text { CSR initiatives, especially the public engagement. }\end{array}$ & Organizations & Self-control & Contra \\
\hline Creativity and Innovation & $\begin{array}{l}\text { The opportunity provided for involvement in alternative proposal (e.g. } \\
\text { design) unleashed the creative and innovative ideas of the contractor and } \\
\text { her team (e.g. introduction of gabion wall). }\end{array}$ & $\begin{array}{l}\text { Individuals/Teams/ } \\
\text { Organizations }\end{array}$ & Self-control & Contra \\
\hline
\end{tabular}


Table 6: Cross-Team Comparison of Drivers of Control

\begin{tabular}{|c|c|c|c|c|c|}
\hline \multirow{2}{*}{ Drivers } & \multicolumn{3}{|c|}{ Project Alpha } & \multicolumn{2}{|c|}{ Project Beta } \\
\hline & Client & Consul & Contra & Dual & Contra \\
\hline \multicolumn{6}{|l|}{ Individual-level } \\
\hline Experience (i.e. type of project) & & $\sqrt{ }$ & $\sqrt{ }$ & $\sqrt{ }$ & \\
\hline Nationality \& Culture & $\sqrt{ }$ & $\sqrt{ }$ & $\sqrt{ }$ & & \\
\hline Trust (across organization) & $\sqrt{ }$ & $\sqrt{ }$ & $\sqrt{ }$ & & \\
\hline Trust (within organization) & $\sqrt{ }$ & $\sqrt{ }$ & $\sqrt{ }$ & $\sqrt{ }$ & \\
\hline Organization Rank & & $\sqrt{ }$ & $\sqrt{ }$ & & \\
\hline Personality & $\sqrt{ }$ & $\sqrt{ }$ & $\sqrt{ }$ & & \\
\hline Status Perception/Expectation & & & & & $\sqrt{ }$ \\
\hline Open Mindedness & & & & & $\sqrt{ }$ \\
\hline \multicolumn{6}{|l|}{ Team-level } \\
\hline Experience (i.e. type of project) & & $\sqrt{ }$ & & $\sqrt{ }$ & \\
\hline Trust (across organization) & $\sqrt{ }$ & $\sqrt{ }$ & $\sqrt{ }$ & & \\
\hline \multicolumn{6}{|l|}{ Organization-level } \\
\hline Top Management Support & $\sqrt{ }$ & $\sqrt{ }$ & $\sqrt{ }$ & $\sqrt{ }$ & $\sqrt{ }$ \\
\hline Trust (across organization) & $\sqrt{ }$ & $\sqrt{ }$ & $\sqrt{ }$ & & \\
\hline Organization Culture & $\sqrt{ }$ & & & $\sqrt{ }$ & \\
\hline Knowledge of Past Performance & & & $\sqrt{ }$ & & $\sqrt{ }$ \\
\hline Joint Venture & & & $\sqrt{ }$ & & \\
\hline Experience (i.e. type of project) & & & & $\sqrt{ }$ & $\sqrt{ }$ \\
\hline Risk Perception & & & & & $\sqrt{ }$ \\
\hline Project Implementation Division & & & & & $\sqrt{ }$ \\
\hline \multicolumn{6}{|l|}{ Project-level } \\
\hline Project Status (i.e. experiment/priority) & $\sqrt{ }$ & & & $\sqrt{ }$ & $\sqrt{ }$ \\
\hline Project Complexity & & & $\sqrt{ }$ & & $\sqrt{ }$ \\
\hline Procurement Arrangement & & & & $\sqrt{ }$ & $\sqrt{ }$ \\
\hline
\end{tabular}

Notes: aAn " $\sqrt{ }$ " under any team indicates the driver manifested itself in the team. 
Table 7: Cross-Team Comparison of Consequences of Control

\begin{tabular}{|c|c|c|c|c|c|}
\hline \multirow{2}{*}{ Consequences } & \multicolumn{3}{|c|}{ Project Alpha } & \multicolumn{2}{|c|}{ Project Beta } \\
\hline & Client & Consul & Contra & Dual & Contra \\
\hline \multicolumn{6}{|l|}{ Individuals } \\
\hline$\overline{\text { Job Satisfaction }}$ & $\sqrt{ }$ & $\sqrt{ }$ & $\sqrt{ }$ & $\sqrt{ }$ & $\sqrt{ }$ \\
\hline Learning & $\sqrt{ }$ & $\sqrt{ }$ & $\sqrt{ }$ & $\sqrt{ }$ & $\sqrt{ }$ \\
\hline Opportunity & & & & & $\sqrt{ }$ \\
\hline Creativity and Innovation & & & $\sqrt{ }$ & & $\sqrt{ }$ \\
\hline \multicolumn{6}{|l|}{$\underline{\text { Teams }}$} \\
\hline Teamwork & $\sqrt{ }$ & $\sqrt{ }$ & $\sqrt{ }$ & & \\
\hline Learning & & & & $\sqrt{ }$ & $\sqrt{ }$ \\
\hline Mutual Understanding & & & & & $\sqrt{ }$ \\
\hline Opportunity & & & & & $\sqrt{ }$ \\
\hline Creativity and Innovation & & & & & $\sqrt{ }$ \\
\hline \multicolumn{6}{|l|}{ Organizations } \\
\hline Less Claims & $\sqrt{ }$ & $\sqrt{ }$ & $\sqrt{ }$ & & \\
\hline Client Satisfaction & $\sqrt{ }$ & & & $\sqrt{ }$ & \\
\hline Less TTA Non-compliance & $\sqrt{ }$ & $\sqrt{ }$ & $\sqrt{ }$ & & \\
\hline Teamwork & $\sqrt{ }$ & $\sqrt{ }$ & $\sqrt{ }$ & & \\
\hline Creativity and Innovation & & & $\sqrt{ }$ & & $\sqrt{ }$ \\
\hline Time Savings & & & $\sqrt{ }$ & $\sqrt{ }$ & $\sqrt{ }$ \\
\hline Cost Savings & & & & $\sqrt{ }$ & $\sqrt{ }$ \\
\hline Learning & & & & $\sqrt{ }$ & $\sqrt{ }$ \\
\hline Opportunity & & & & & $\sqrt{ }$ \\
\hline Less Public Complaints & & & & & $\sqrt{ }$ \\
\hline
\end{tabular}

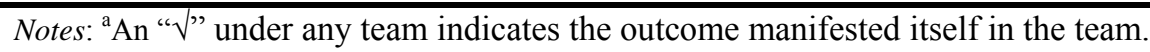

